\title{
Structural adjustment policies and productive efficiency of socialist enterprises*
}

\author{
Janez Prasnikar
}

Unir._sity' of Ljubljana. 61000 Ljubljana. Yugoslavia

\section{Jan Svejnar}

University of Pittshurgi, Pittshurgh, PA 15260, USA

\section{Mark Klinedinst}

University of Southern Mississippi, Hattieshurg, MS 39406, USA

Received December, 1989, final version received, April 1991

The paper uses panel data from a five percent stratified random sample of Yuzuslav indus: $:$ ial enterprises to test several hypotheses about the determinants of productive efficiency. The estimating procedure selects the production function best supported by the data and allows for industry-specific production function parameters as well as from firm-specific fixed or random effects. The instrumental variable estimates suggest that productive efficiency is unaffected by the four structural/policy variables whose effect we examine: the extent of export orientation. joint venture status, divisionalization of the firm, and the firm's market share.

\section{Introveraction}

The ongoing economic reforms in Central/East Europe and the USSR have received major attention in the economic as well as popular press. While analysts differ in their assessment of the optimal set and sequencing of reform measures, there is little disagreement that improved enterprise

We would like to thank Avner Ben-Ner, Josef Brada, John Cable, Evsey Domar, Derek Jones, Arnold Katz, and Jeff Pliskin for useful comments. The earlier drof! of this perer also benefitted from presentaiions at the $\mathbf{9 8 6}$ Cornell-Hamilton College Conference on the Economics of Participatory, Profitsharing and Worker-Owned Firms and seminars at Hamilion College, University of Pittsburgh, the 1990 World Econometric Congress in Barcelona, and SUNY Stony Brook. Any remaining errors are ours. Jan Svejnar's research was in part supported by NSF Grant No. SES882 and NATO Co'iaborative Research Grant No. RG85/0432 1957. Janez Prasnikar and Jan Svejnar also benefited in part from Crant No. 802-92 of the National Council for Soviet and Easi European Research. 
performance is a keystone to any viable economic program. Productive inefficiency is widely regarded as the Achilles' heel of socialist enterprises, but policy formulation has been hampered by a lack of rigcrous empirical studies at the firm-level. Enterprise-level policies and reforms have therefore been based primarily on case studies and institutional insights. They have stressed a number of features, including greater exposure of domestic firms to foreign trade activities as a means of gererating foreign exchange and learning superior techniques of management and marketing, the infusion of modern technology and know-how through the cooperation of domestic firms with western counterparts, restructuring of (frequently giant) firms into more efficient units, introducing greater competition into the monopolistic markets and, interestingly, also worker participation in management. ${ }^{1}$

Yugoslavia has since the 1950 s been known as the pioneer of 'workers' self-management' and its economic success as well as failures have been rather indiscriminately attributed to this special system. What has been less publicized is that since the 1960s, the Yugoslavs provided for considerable enterprise autonomy and decentralized decisionmaking, which have been accompanied by export incentives for firms, great reliance on western technology, and the establishment of significant joint venture partnerships with western îrms.

In 1989, the Yugoslavs passed a new Law of Enterprise, which eliminated many of the compulsory features of iabor-management (including the divisionalization of firms) and legalized firms with a variety of property rights and decisionmaking structures. ${ }^{2}$ In the area of enterprise policies and regulations, one hence observes a sudden convergence of the centrally planned and labor-managed systems. Moreover while the rate of change in Czechoslovakia, Hungary and Poland has been phenomenal, there are important lessons to be learned from Yugoslavia's experience with various forms of enterprise autonomy, use of western capital and extent of joint ventures with western firms, foreign trade exposure of individual enterprises, and attempts to correct the enormous (go:ernment-induced) concentration in the product market. In this paper we use panel data from a unique stratified random sample of Yugoslav enterprises to estimate the effects of these structural/policy features on productive efficiency of Yugoslav socially owned firms. The results are of course primarily relevant for Yugoslavia. However, as our discission indicates, they are also of interest for " ther reforming socialist economies and for developing countries in general.

\footnotetext{
'Poland, Hungary and the Soviet Union have passed law.. givirg workers varying powers to elect enterprise directors and influence specific enterprise decisions. They have hence instituted a participatory system which contains elements of both West German-type codetermination and Yugoslav labor-management.

${ }^{2}$ These include domestic private and foreign owned firms with no worker ccntrol. Since the passing of the $1989 \mathrm{law}$, Siemens of West Germany has for instance acciuired a division of Iskra Electronics and groups of Yugoslav workets have purchased assets of a number of socially owned firms.
} 
The paper is organized as follows. In section 2 we briefly discuss the Yugoslav institutional framework, describe the data set and explain the choice of the structural/policy variables whose productivity impact we estimate. In section 3 we outline the estimating framework and in section 4 we present the econometric results. In section 5 we discuss the policy implications of our findings.

\section{The institutional framework, data and the structural/policy variables}

Since the early 1950s, the Yugoslav economy has displayed a number of particular features, some of which are Yugoslav-specific, while others are typical of either developing or centrally planned economies. As in all developing and Soviet-bloc countries, fast growth has been the principal economic goal. The gradual introduction of labor-management in the early 1950s did not diminish this priority because government regulations ensured that social capital would be steadily augmented by the reinvestment of over 30 percent of the gross material product (GMP). These high investment rates have been the trademark of both Yugoslavia and the Soviet bloc countries, but only a few developing countries have matched this record. Where the Yugoslav development strategy deviated from the traditional Soviet mode! (and came closer to the practices of many developing and transforming socialist economies) is in the significant decentralization of economic decision-making and, since 1965 , also in the great reliance on western technology. ${ }^{3}$

Yet, despite the relative abundance of labor and investment funds, systemic flexibility and easy access to advanced technology, the Yugoslav economy (like other socialist economies) experienced a major slowdown between the early 1950 s and late $1980 \mathrm{~s}$. As a result, numerous economic reforms have been increasingly concerned with economic efficiency both economy-wide and at the enterprise level. ${ }^{4}$

An examination of the data indicates that the Yugoslav economy indeed grew rapidly until 1960 , displayed a highly varying but still respectable growth rate in the 1961-1979 period, and suffered stagnation and decline in the 1980s. The major slowdown of economic growth in the 1980s ushered in an IMF program in 1981 and induced the government to launch an

\footnotetext{
${ }^{3}$ Indeed, virtually all technology in Yugoslavia is imported and domestic research and jevelopmert is virtually non-existent [see Prasnikar (1983) and Gomulka and Ostojic (1984)]. In contrast, Soviet bloc countries did not import significant amounts of Western technology until the 1970s and western machinery has never become a dominant feature of these economies [see for instance Fallenbuchl (1983), Terrell (1990)].

${ }^{4} \mathrm{~A}$ relaied goal has been the reduction in income differentials among the six republics of Slovenia, Croatia, Serbia, Bosnia-Herzegovina, Macedonia, and Montenegro, and the two autonomous provinces of Vojvodina and Kosovo.
} 
economic stabilization program in 1982. This effort at restructiring the economy and providing strong incentives for growth was accompanied by an IMF standby agreement and joined by the first Worid Eunk structural adjustment loan. As the growth record to date indicates, the results of this and the following programs have so far been disappointing.

The Yugosiav productivity problem has also attracted the attention of many academic economists. Numerous studics, inciuding Fräksvic (1967), Bazler and Madzar (1968), Horvat (1969), Vujkovic (1972), Sapir (1980), Nishimizu and Page (1982), Bajt (1983), Estrin, Moore and Svejnar (1988), and Bateman, Nishimizu and Page (1988) have used industry-level data in an attempt to identify the sources and rate of growth of productivity in Yugoslav industry. ${ }^{5}$ Unfortunately, no study has been able to use enterprise-level data and thus avoid the problems of (a) aggregation bias anc the gererally poorer quality of aggregate data, (b) high correlation am's'ng aggregate time series variables, and (c) inability to estimate more complicated behavioral models requiring considerable degrees of freedom. ${ }^{6}$ Morəover, no study has been able to construct variables which would permit a direct examination of the most important issues underlying the recent policy debate and the restructuring of the Yugoslav economy.

\subsection{The data}

in the pressnt paper w'e use a unique five-year balanced panel of data on 120 Yugosiav enterprise's to examine the effects of some of the most important structural and policy variables on productive efficiency of Yugoslav enterprises between 1975 and 1979. The data came from a five percent random sample of 150 Yugoslav industrial enterprises ('Nork Organizations of Associated Labor - W'OALs) stratified by region ard industry. The fiveyear panel covers the period immediately following the enactment of the 1974 constitution and preceding the 1982 stabilization program. The data hence enable us to examire the determinants of productive efficiency after the constitutional reforms of the mid 1970 s were effected and they also permit one to assess whether the policies pursued sirce 198: have been firmly grounded in the empirical reality of the late 1970 s. In this context, we test two hypotheses that have been advanced with respect to the productivit!

\footnotetext{
5'hey parallel similar industry-level studies carried sut on the Soviet and East European data [see e.g. Weizman (1970 and 1979). Whitesell (1985). Kemme (1987) and Terrell (1990)].

"See Kuh (1963) for the classical statement of trese problems. The lack of reliance on firmlevel data is caused by the fict that Yugosiav firm-fevel data ase normally treated as

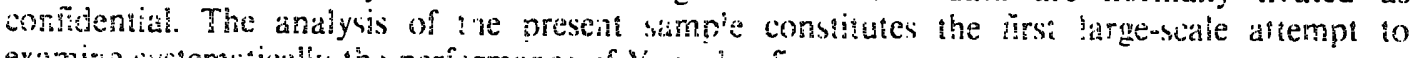

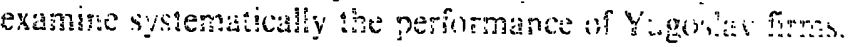


(growth) of developing economies in general, and thus have broader policy relevanie.

\subsection{The structurul/policy variables}

Export orientation. The growing emphasis on a superior export perforrnance $^{7}$ and the high reliance of Yugoslav firms on technolicgy impor , , lent us to explore the extent to which enterprise expori orientation tends to increase productive efficiency. Emphrsis on export performance has always been part of Yugoslav policy in view of the limited domestic market. However, the principles of the 1974 constitution, elaborated in the 1977 Law on Foreign Trade and Foreign Exchange, linked each firm's foreign exchange allocation more closely to its export performance and the sentiment that export oriented firms tend to be more efficient has been growing.

Numerous wesiern studies have also documented a positive association between exports and growth at the aggregate (national) level in many developing countries. ${ }^{8}$ Mereover, Balassa (1986) has argued that the superior growth performance of the out $y$ ard-oriented newly industrialized countries (NICs), relative to that of th: inward-oriented NICs and of Yugoslavia and Hungary, is due to the positive effect of exports on growth. Our data set contains detailed information on the exports of each WOAL and we are therefore able to provide microeconomctric evidence for the so far largely macroeconomic debate. The evidence is especially relevant in the context of stabilization adjustment policies because the World Bank and IMF have stressed the desirability of an export oriented economic strategy on both foreign exchange and efficiency grounds.

Joint Ventures. The merits of joint ventures between domestic and foreign (western) firms have been debated in Yugoslavia, the centrally planned and developing countries for decades, but empirical evidence on the subject is still scant. The virtual non-existence of the Yugoslav R \& D sector has led many observers to argue that a liaison with technology advanced foreign partners would improve the technological and managerial know-how, and therefore productivity, in Yugoslav firms. ${ }^{9}$ The arguments against joint ventures have stressed the limited willingness of the foreign firms to share the most advanced technology and their ability to 'exploit' the domestic partners through transfer pricing and limited risk-sharing. In view of the importance of these conjectures for public policy, one of our aims in this paper is to

\footnotetext{
${ }^{7}$ Yugoslav foreign uebt increased from $\$ 2$ billion in 1970 to $\$ 22$ billion in 1989 and the pubiic policy emphasis on expori growth has risen accordingly.

${ }^{-}$See e.g. Michaely (1977. 1979), Batassa (1978, i985), and Jung and Marsha! (1985).

${ }^{\circ} \mathrm{At}$ present, this arguraen! for joint venturcs is also very forcefully articulated in other Central/East European countries and the Soviet Union.
} 
establish whether Yugoslav firms which operate as joint ventures with foreign partners display a significantly superior productive behavior, ceteris paribus, than other firms. ${ }^{10}$

Enterprise structure. The 1971 constitutional amendment and the 1974 constitution aimed at advancing workers' self-management by breaking existing enterprises into the smallest technically and commercially viable units (the Basic Organizations of Associated Labor - BOALs) and functionally integrating these semi-autonomous groups of workers into higherlevel organizations - the Work Organizations (WOALs) and the Composite Organizations of Associated Labor (COALs). Individual BOALs were to be independent in most of their economic decisions, including those on the distribution of BOAL income, investment, exports, and imports. Moreoever, inter-BOAL transactions were supposed to be guided by internal market forces (bargaining) within a vertically integrated system.

In practice the WOALs remained the closest counterparts to Western enterprises, but the BOALs retained independence which usually exceeded that of individual divisions of Western corporations. ${ }^{11}$ The main point of contention since 1974 has been whether the divisionalization of firms into BOALs has increased productivity by augmenting information flows and workers' effort through their greater identification with the workplace, or whether the system fragmented enterprises into excessively minute units which prevented efficient management and hampered productivity. ${ }^{12}$ While these hypotheses have never been tested, the proponents of the latter view have prevailed politically and the 1989 Law of Enterprise is effectively piiasing out the divisional (BOAL) system. In this paper, we assess the impact of enterprise divisionalization on efficiency by using information on the number of BOALs within the 120 sampled WOALs. The results are sf interest $f_{C}:$ Yugoslavia as well as for the other East European economies that are in the process of breaking up existing firms into smaller units.

Market structirit. The conversion of enterprises into BOALs, WOALs and COALs also altered significantly the degree of industrial concentration in Yugoslavia. Petrin's (1981) and Sack's (1983) calculations indicate that the

\footnotetext{
${ }^{10}$ It should be noted that the official Yugoslav policy toward Yugoslav-foreign joint ventures was benevolent between 1967 and $197 \%$ restrictive during 1978-1984 period, and again liberal since the 1984 Amendment to the Law on Joint Ventures. Although some of our data points fall into the restrictive period governed by the 1978 Law on Joint Ventures, all sampled iirms estabiished their venturec hefore 1978 and hence nnerated under the more liberal principles of the 1967 law.

"For detailed accourits of the Yugosiav enterprise system see Tyson (1980), Sacks (1983) and Prasnikar and Svejnar (1988).

${ }^{1}$ 'See e.g. Pucko (1974), Pjanic (1983), Tyson (1980), Estrin (1984), and Prasnikar and Svejnar (1988).
} 
1971-1974 constitutional reform substantially increased the number of firms when the BOAL is taken as the unit of account, but that industrial concentration increased when the number of WOALs is considered. The Yugoslav economy has of course always been characterized by high industrial concentration, the effects of which have been the subject of a long-term debate by both Yugoslav and western economists. ${ }^{13}$ In this paper we use WOAL-specific data and managerial information to construct a measure of each firm's market share and assess whether the effect of market power on productive efficiency is positive or negative. The concentration of the market share variable is described in the Appendix.

Regional Differences. One of the principal reasons for the 1974 constitutional reform was the acute and seemingly intractable problem of regiona! differentials. The GMP per capita in the most advanced region of Slovenia exceeded that of the least developed Kosovo by 292 percent in 1954 but by 1975 this differential stood at 509 percent. Similarly, the relative GMP ner capita differential between all the more developed republics and autonomous provinces (RAPs) on the one hand and the less developed ones on the other hand evolved from 55 percent in 1954 to 95 percent in $1975 .{ }^{14}$ The internal Yugoslav consensus has been that the limited economic base in the less developed regions has accounted for this ongoing problem. The disagreement between the more and less developed RAPs lies in the specific nature of and remedies for the problem. The more developed RAPs have argued that limited managerial and technical expertise in the less developed RAPs generates lower productive efficiency of their firms and that a larger unrestricted transfer of investment funds to the less developed RAPs would be inefficient. The less developed RAPs have viewed the problem as one of insufficient inflow of investment funds into their regions and they have been contesting the claim that their enterprises are less productive.

The debate continues to date and the growing inter-RAP differences currently constitute one of the main threats to the survival of the Yugoslav federation. Regional differentials also constitute major problems in Czechoslovakia and the Soviet Union. Since our data set constitutes a stratified random sample of nirms across all the RAPs, it enables us to provide the first test of the hypothesis that productive efficiency of enterprises varies systematically with the level of economic development of regions.

In sum, the main structural and policy features of the Yugeslav system as well as the developments in other transforming socialist economies and many

\footnotetext{
${ }^{13}$ See Horvat (1971), Petrin (1981), Sacks (1983), Prasnikar (1983), Estrin and Svejnar (1985), and Estrin, Moore and Svejnar (1988).

${ }^{14}$ See World Bank (1983). Overall, Bosnia-Herzegovina, Kosovo, Macedonia, and Montenegro are classified as the less developed regions, whilc Slovenia, Croatia. Vojvodina and Serbia are considered to be the more develoned ones.
} 
developing countries suggest that it is of ccusiderable policy interest to assess the productive efficiency - ffects of enterprise export orientation, joint venture production with foreign firms, enterprise divisionalization into smaller units, product market concentration, and regional differences.

\section{Estimating framework}

Since the assumptions of profit maximization (cost minimization) and the existence of competitive prices are not tenable in Yugoslavia, our approach is to use a production rather than cost function framework in estimating the impact of the policy/structural variables on productive efficiency. ${ }^{15}$ Because no prior estimates of production technology exist at the level of individual cnterprises, our empirica! strategy is to embed thi structural and policy variables into translog and Cobb-Douglas production functions and test which form of the production function is best supported by the data.

Letting $Q=$ output, $K=$ capital, $L=$ labor, $t=$ time trend, and $Z=$ vector of the structural/policy variables, the Froduction function can be formulated in a general form as

$$
Q=f(t, Z) g(L, K)
$$

where $g$ is an input function and $f$ is a disembodied productive efficiency function whose value varies cer time and across institutional/policy settings. In empirical work we approxi nate eq. (1) by various augmented forms of the Cobb-Douglas and translog production functions, starting with the least restrictive specifications permitted by the data and gradually imposing constraints that are found acceptable on the basis of appropriate $\chi^{2}$ tests.

We permit production function parameters to be industry-specific and allow for firm-specific fixed or random effects within each industry and region. Assuming that $f()$ and $g()$ are additively separable in logarithms, the estimating equation for the fixed effects specification may be written as

$$
\ln Q=\left[I_{N} \otimes j_{T} j_{N} \otimes\left(l_{t-1} O^{\prime}\right)^{\prime} Z X\right][\alpha \beta \gamma \delta]^{\prime}+\varepsilon,
$$

where $I_{N}$ is an $N \times N$ identity matrix, $N=120, T=5, Q^{\prime}=\left(Q_{1}^{\prime}, Q_{2}^{\prime}, \ldots, Q_{120}^{\prime}\right)$, $Q_{i}=\left(Q_{i 1}, Q_{i 2}, \ldots, Q_{i s}\right)^{\prime}$, and $j_{T}=(1,1, \ldots, 1)^{\prime}$ and is of dimension $T \times 1 . \varepsilon$ is defined in the same manner as $Q$.

The random effects model may be written as

$$
\ln Q=\left[j_{N} \otimes\left(I_{t-1} C^{\prime}\right)^{\prime} Z X\right][\beta \gamma \delta]^{\prime}+\lambda \otimes j_{T}+\varepsilon,
$$

\footnotetext{
${ }^{15}$ Another reason for using the production rather thair cost function can be found in Mundlak (1989).
} 
where $\lambda=\left(\lambda_{1}, \lambda_{2}, \ldots, \lambda_{N}\right)$. In eqs. (2) and (3), $\beta$ is the vector of parameters corresponding to annual time dummy variables, $?$ ' is the vector of parameters corresponding to the vector $Z$ of the siructural/policy variables, and $\delta$ is the vector of parameters for the capital and labor inputs $X$. Parameters $\alpha$ in eq. (2) reflect the firm-specific fixed effects.

In operationalizing the hypotheses advanced with respect to the structural/ policy variables, we include as elements of $Z$ the ratio of the value of firm's exports to the total value of firm's sales, a dummy variable coded 1 if the firm is a joint venture with a foreign firm and 0 otherwise, ${ }^{16}$ the number of workers per BOAL standardized by ine industry average, the firm's sales as a proportion of the total volume of sales (transactions) on its regional market, and either individual RAP dummy variables or one dummy variable for al! the more developed regions (Slovenia, Croatia, Vojvodina, and Serbia). Output is measured as value added of each firm in constant 1975 prices, the capital input is measured by fixed assets expressed in constant 1975 prices and adjusted for capacity utilization, and labor is expressed in unskilled worker equivalents (see the appendix for a description).

Because several of the explanatory variables may be endogenous, we have instrumented all the regressors except for the regional and industry dummy variables and used the Sargan-Wu instrument validity test to compare the relative merit of the least squares and instrumental variable (IV) specifications. ${ }^{17}$ In order to select the functional form best supported by the data, we have used a Wald-type [Kiviet (1985)] test, described in the note to tahle 3 , to evaluate the parameter restrictions of the various specifications.

Since our interest is in making inferences from the enterprise sample about the population of all firms, a random effects model is philosophically perhaps the more appropriate specification. The generalized least squares (GIJS) estimator corresponding to the random effects model is also the best liuear unbiased estimator (BLUE) when $\lambda$ is assumed random, whereas the fixed effects (within group) estimator is unbiased and consistent but not BLUE in this case. ${ }^{18}$ Moreover since some of our explanatory variables (e.g. the market share and the presence of a joint venture) are firm-specific and almost time invariant, the random effects specification may be preferable for estimating their effects.

The problem with the random effects model of course arises when $\lambda$ is correlated with some elements of $X$ or $Z$. The unbiased nature of the fixed effects estimator and the bias inherent in the GLS random effects estimator suggest that the fixed effects specification would be superior in such a case.

\footnotetext{
${ }^{16}$ Unfortunately, it was impossible to obtain data on the extent of joint venture collaboration (e.g., a share of output produced under a joint venture agreement).

${ }^{17}$ The instrumental variables used were the value of CECD imports, the value of Yugoslav imports, an index of Yugoslav industrial prices, and firm d umniy variables.

${ }^{18}$ Sec e.g. Hsiao (1986).
} 
In order to select between the fixed and random effects model, we carry out the Hausman and Taylor (1981) specification test, the details of which are given in the note to table 3 . As we indicate presently, the random effects model comes out as the dominant specification by the appropriate $\chi^{2}$ criterion.

\section{Empirical results}

As the summary statistics in table 1 indicate, the sample displays substantial variance in all the relevant variables. Moreover, the mean statistics show that the average firm exports 12.3 percent of its output, commands 42.4 percent of its product market, and consists of relatively large divisions (BOALs) that average 316 workers. Almost 15 percent of the sampled firms operate as joint ventures with foreign firms. The regional disiribution of firms reflects the uneven levels of development across the country, with the largest number being located in Croatia and Slovenia (25 and 20.5 percent, respectively) and the smallest number in Montenegro and Kosovo (3.3 and 2.5 percent, respectively). Industry allocation of firms varies from 10 percent in non-metal processing to 32.5 percent in metallurgy and metai processing.

Before reporting the results of the more systematic hypothesis testing, we present in table 2 simple correlation coefficients among the main variables. As the correlation matrix indicates, labor productivity is significantly positively correlater with capital intensity and enterprise market share. It displays a weaker positive correlation with the joint venture dummy and, surprisingly, a weak negative correlation with the extent of enterprise export orientation There is virtually no correlation between the output-labor ratio and the (industry standardized) number of workers per BOAL. The simple correlation coefficients among the remaining regressors are very low and multivariate tests that we performed also suggest that multicollinearity is not a problem in ou. regression $\mathrm{sp}$-ifications.

Within the augmented production function framework of eq. (1), the Hausman and Taylor test invariably favors the random effects model at the five percent significance test level. Moreover, the Sargan-Wu instrument validity test indicates that the IV estimators are preferable to the least squares ones in all the specifications. In table 3, we therefore present the random effects IV estimates from the principal production function specifications.

Columis $(1)-(6)$ in table 3 contain parameter estimates of one translog and five Cobb-Douglas specificetions. The iranslog estimates are reported primarily for the sake of completeness because all translog specifications are strongly dominated by their Cobb-Douglas counterparts. The CobbDouglas specifications in column (2)-(5) allow for ind wstry-spedinc techno- 


$$
\text { Tar : : } 1
$$

Summary statisics of relevant variables. ${ }^{a}$

\begin{tabular}{|c|c|c|c|}
\hline & & Mean & $\begin{array}{l}\text { Standard } \\
\text { deviation }\end{array}$ \\
\hline $\bar{Q}$ & $\begin{array}{l}\text { Overall } \\
\text { More developed RAPs } \\
\text { Less developed RAPs }\end{array}$ & $\begin{array}{l}0.8 E 5 \\
0.7 E 5 \\
1.1 E 5\end{array}$ & $\begin{array}{l}1.7 \mathrm{E} 5 \\
1.1 \mathrm{ES} \\
2.6 \mathrm{E} 5\end{array}$ \\
\hline$L$ & $\begin{array}{l}\text { Overall } \\
\text { More developud RAFs } \\
\text { Less developed RAPs }\end{array}$ & $\begin{array}{l}1,717 \\
1,449 \\
2,560\end{array}$ & $\begin{array}{l}2,820 \\
2,187 \\
4,131\end{array}$ \\
\hline K & $\begin{array}{l}\text { Overall } \\
\text { More developed RAPs } \\
\text { Less developed RAPs }\end{array}$ & $\begin{array}{l}2.1 \mathrm{E} 7 \\
1.5 \mathrm{E} 7 \\
4.2 \mathrm{E} 7\end{array}$ & $\begin{array}{l}8.6 \mathrm{E} 7 \\
3.4 \mathrm{E} 7 \\
1.6 \mathrm{E} 8\end{array}$ \\
\hline$K ! \mathbf{L}$ & $\begin{array}{l}\text { Overa!l } \\
\text { More developed RAPs } \\
\text { Less developed RAPs }\end{array}$ & $\begin{array}{l}86.4 \\
86.8 \\
85.2\end{array}$ & $\begin{array}{l}87.8 \\
88.4 \\
86.1\end{array}$ \\
\hline Export/revenue overall & $\begin{array}{l}\text { More developed RAPs } \\
\text { Less developed RAPs }\end{array}$ & $\begin{array}{l}0.123 \\
0.119 \\
0.234\end{array}$ & $\begin{array}{l}0.150 \\
0.138 \\
0.165\end{array}$ \\
\hline Market share overall & $\begin{array}{l}\text { More developed RAPs } \\
\text { Less developed RAPs }\end{array}$ & $\begin{array}{l}0.424 \\
0.425 \\
0.422\end{array}$ & $\begin{array}{l}0.282 \\
0.280 \\
0.291\end{array}$ \\
\hline \multicolumn{2}{|c|}{$\begin{array}{l}\text { Labour/BOAL (workers) overall } \\
\text { More developed RAPs } \\
\text { Less developed RAPs }\end{array}$} & $\begin{array}{l}316 \\
282 \\
124\end{array}$ & $\begin{array}{l}333 \\
256 \\
491\end{array}$ \\
\hline
\end{tabular}

Proportion of firms by region

Slovenia

Croatia

0.250

Vojvodina

Serbia

$0.14 !$

Bosnia/Herzegovina

0.166

Montenegro

0.116

Macedonia

0.033

0.067

Kúsovo

0.025

Proportion of firms by industry

Energy, chemicals and paper

0.125

Metallurgy and metal processing

0.325

Non-metal processing

0.100

Wool, textiie, leather and rubber

0.342

Foud, tobacco an i miscellarejus

0.108

Proportion of firms with a foreign joint centure

Overall

More developed RAPs

0.558

Less developed RAPs

0.103

${ }^{a}$ All variables are defined in the appendix. Values are in thousands of cinars and they are expressed in constant (1975) prices. 
Table 2

Correlation matrix of the main variables.

\begin{tabular}{|c|c|c|c|c|c|c|}
\hline & $Q / L$ & $K / L$ & $J V$ & $\begin{array}{l}\text { Exports/ } \\
\text { rev. }\end{array}$ & $\begin{array}{l}\text { Market } \\
\text { share }\end{array}$ & $L / \mathrm{BOAL}$ \\
\hline$Q / L$ & 1 & - & - & - & - & - \\
\hline$K / L$ & 0.54 & 1 & - & - & - & - \\
\hline$J V$ & 0.11 & 0.10 & 1 & - & - & - \\
\hline Exports/rev. & -0.10 & -0.03 & 0.52 & 1 & - & - \\
\hline Market share & 0.27 & 0.16 & 0.13 & -0.15 & 1 & - \\
\hline$L / B O A L$ & 0.03 & 0.22 & -0.00 & 0.63 & -0.04 & 1 \\
\hline
\end{tabular}

logy but they vary in their treatment of regional and industry effects. The Cobb-Douglas specification in column (6) is the most constrained one, forcing the labor and capital coefficients to be invariant across industries. The specifications in columns (5) and (6) dominate those in columns (i) $-(4)$, with spicification (6) dominating that in (5) at the 5 percent but not 1 percent statistical test level.

As the first four rows in table 3 indicate, we cannot reject the hypothesis that productive efficiency of the Yugoslav firms is unaffected by any one of the four structural/policy $(Z)$ variables - the extent of export orientation, whether or not the firm operates as a joint venture with a foreign firm, the degree of divisionalization of the firm, and the firm's market share. The insignificance of all the coefficients has led us to estimate more constrained specifications (rejected by statistical tests) in order to assess if and when any of the $Z$ variables gain significance. Our finding is that it is very difficult to generate statistically significant coefficients for these variables. Basically, we were only able to generate positive and significant coefficients for the market share variable in certain fixed effects specifications.

The estimated coefficients on the regional dummy variables suggest that the more advanced RAPs are more efficient but the individual estimates in columns (1)-(3) of table 3 are statistically insignificant. However, when one compares the average efficiency in all the firms of the more advanced RAPs relative to those of the less developed regions [columns (4)-(6)], one identifies a statistically significant $18-20$ percent differential, which is unaffected by the treatment of technology and industry effects. The results hence suggest that firms in the more developed RAPs are on average more productive than their less developed RAP counterparts, but also that considerable intra-regional variation in efficiency exists.

The technologically most constrained specification in column (6) of table 3 suggests that Yugoslav firms iend to experience decreasing returns to scale. This overall finding is supported to varying degrees at the more disaggregated (industry) level by estimates from all but one industry (non-metal processing). 


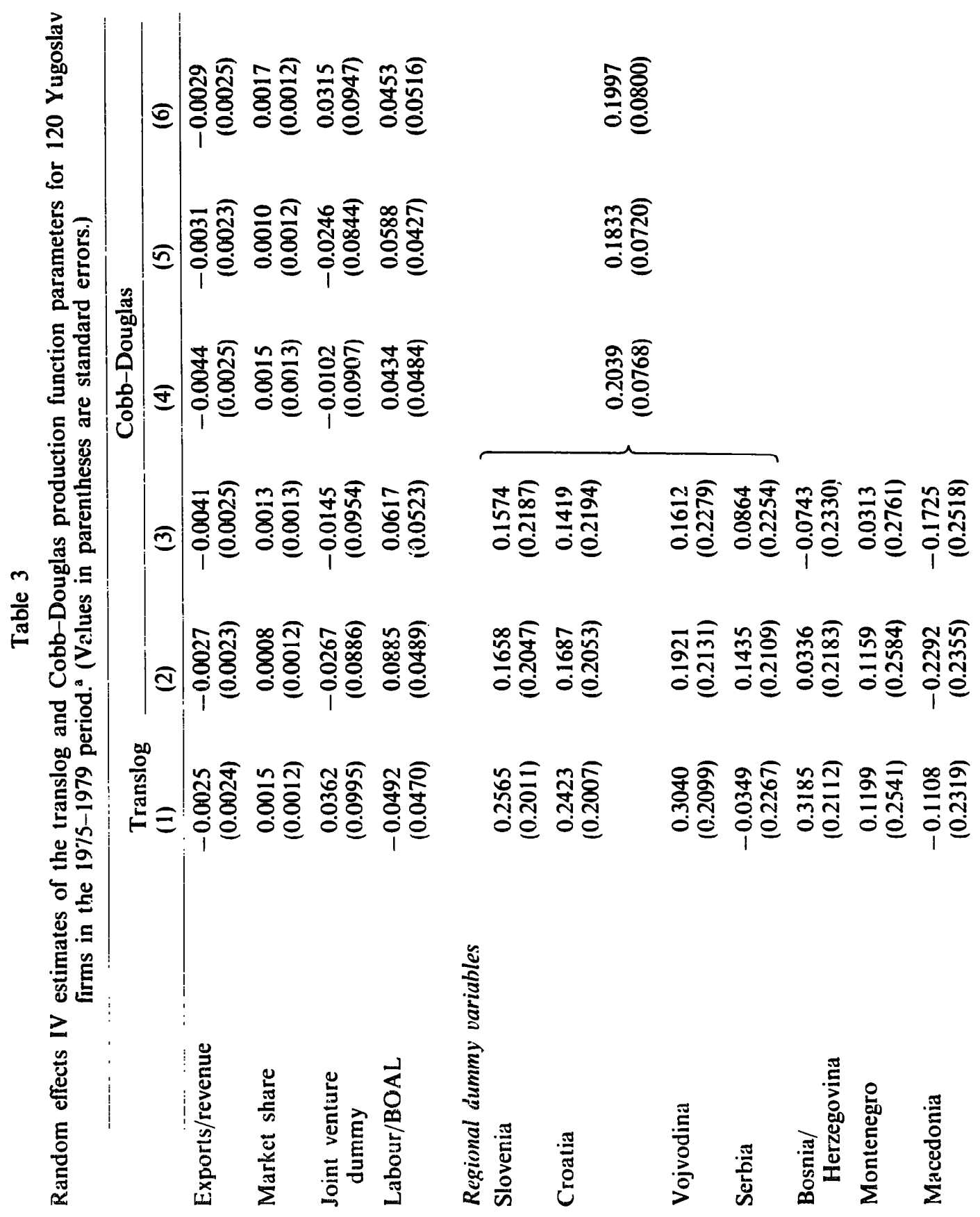




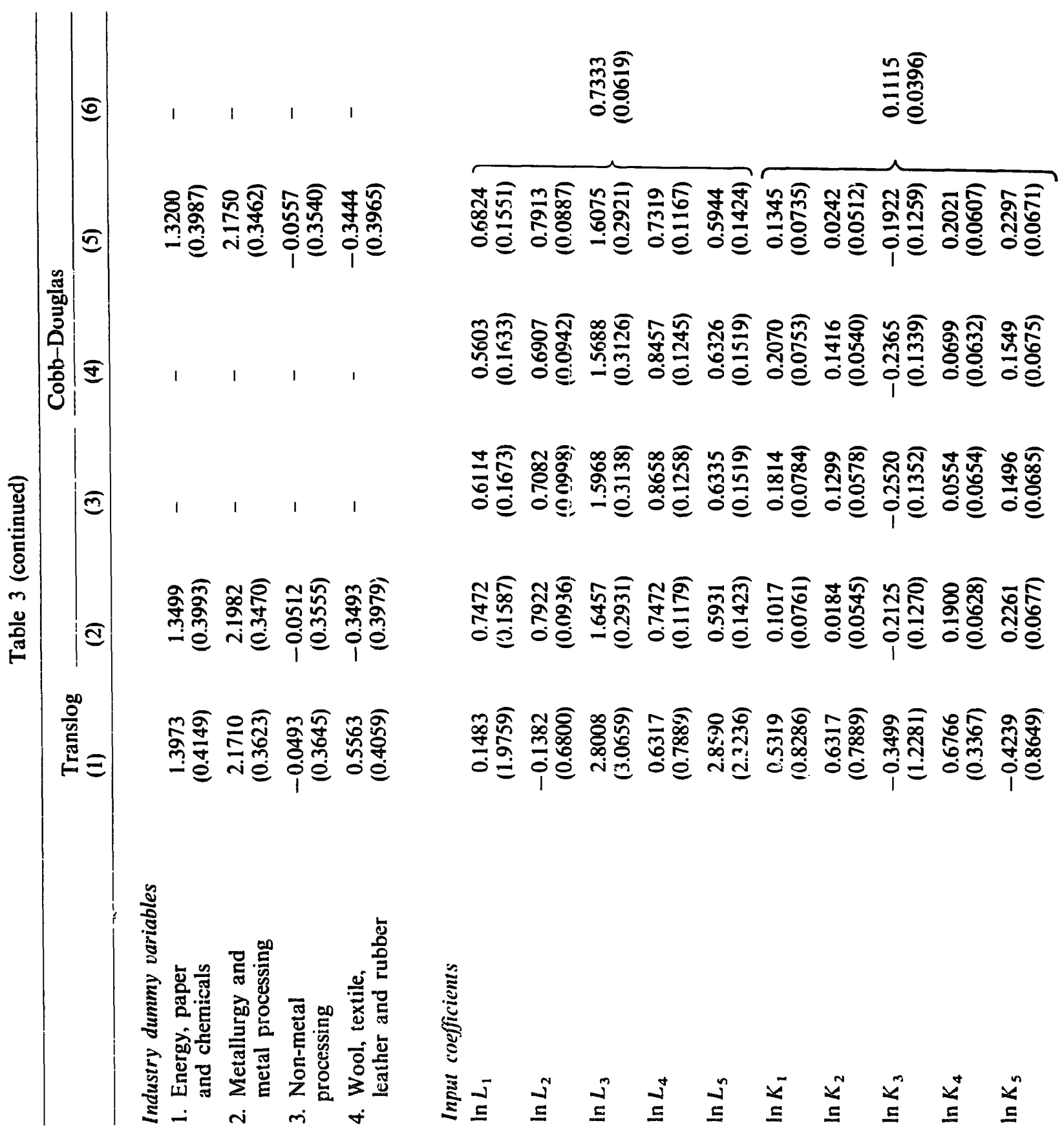




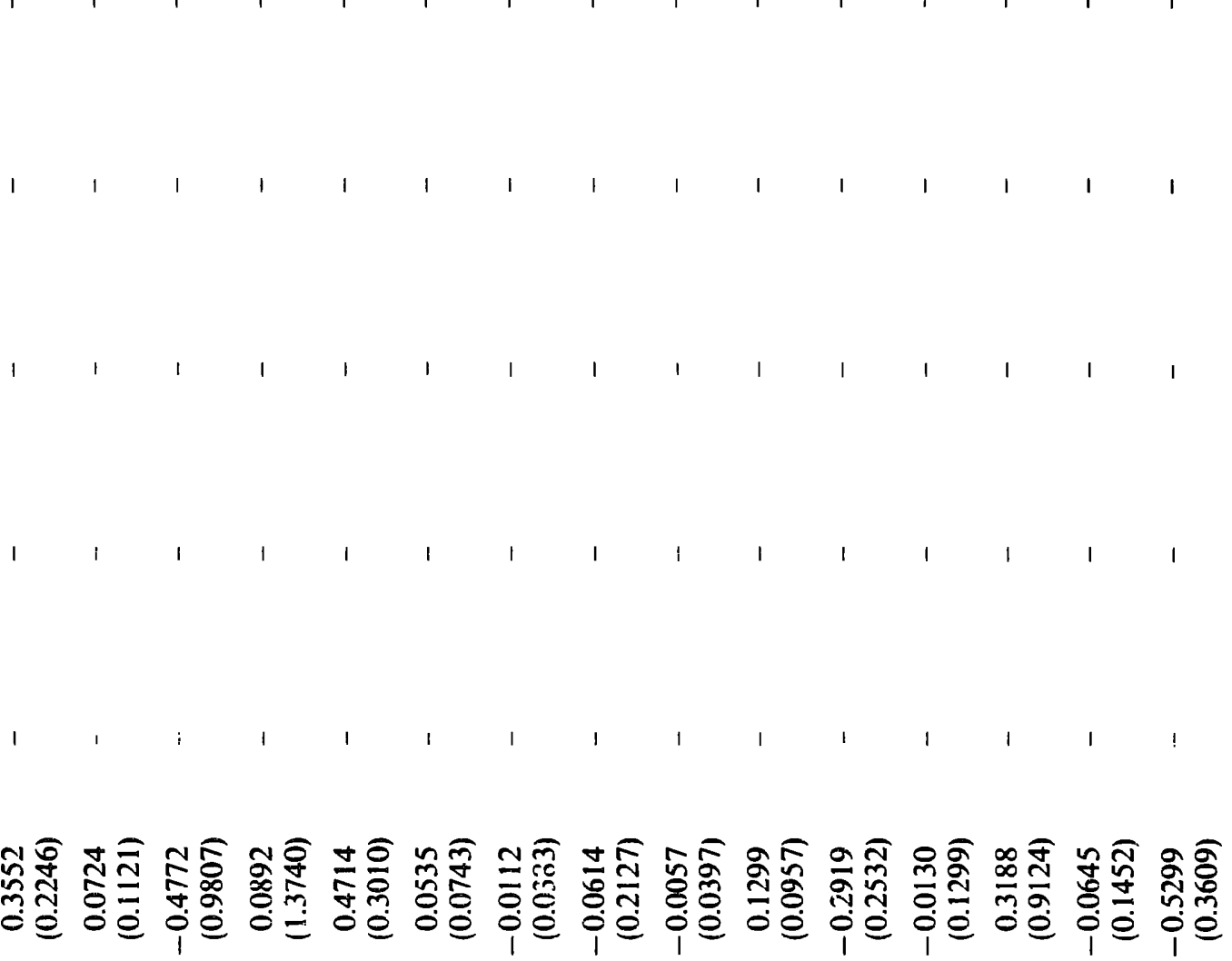

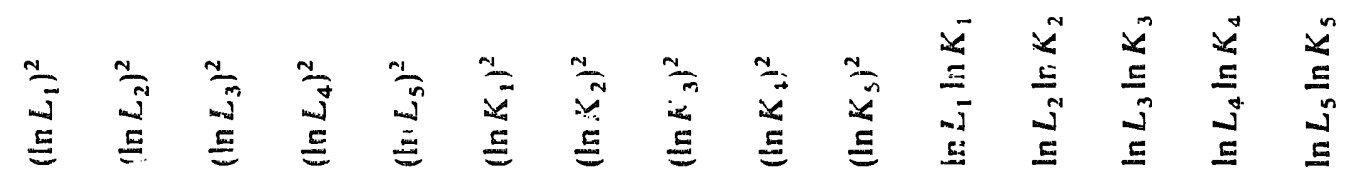




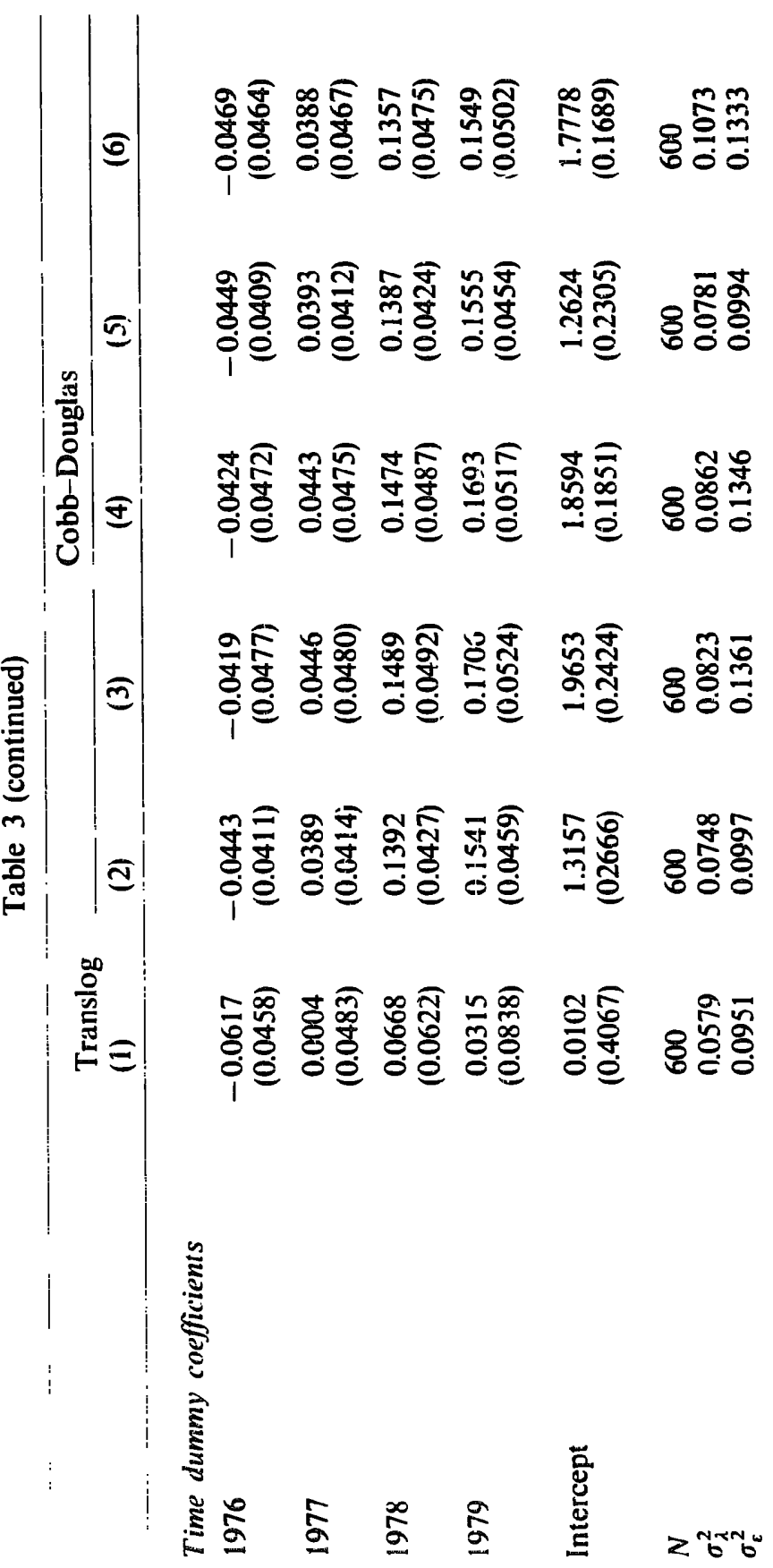




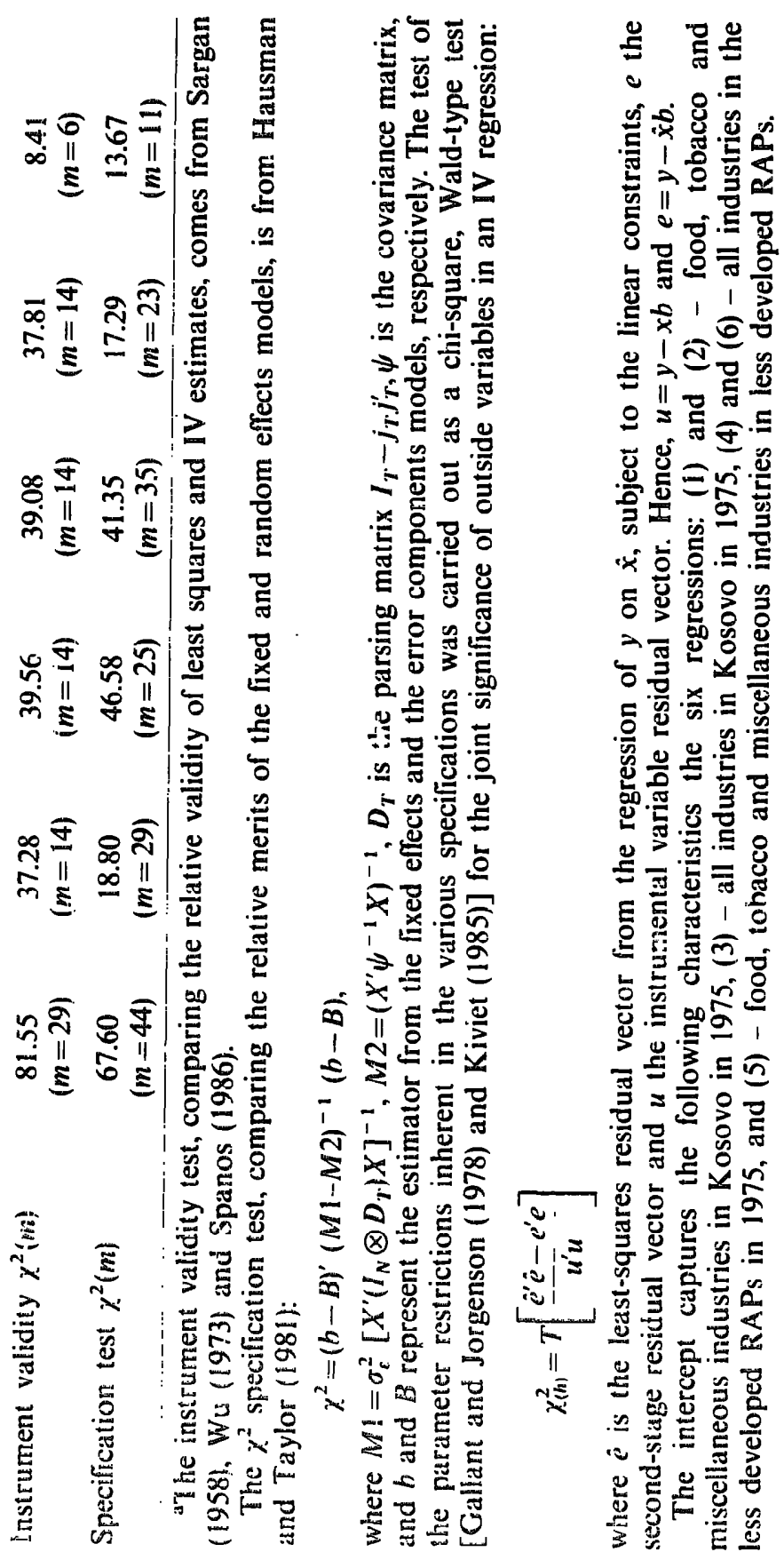


Finally, the annual time dummy variables suggest that, after being stagnant in the mid 1970s, productive efficiency increased in the late 1970 s, possibly because of an impact of the rapidly rising (debt-financed) technological imports.

\section{Policy implications}

Reforming socialist economies have great aspirations that they will improve enterprise efficiency through measures which include greater foreign trade exposure, formation of joint ventures with foreign firms, restructuring firms to an optimal size, and reducing the monopolistic tendencies in the socialist market structure. Similarly, many developing countries have placed emphasis on enhancing enterprise efficiency through these means. Our analysis of productive efficiency in a siratified randiom sample of 120 Yugoslav firms suggest that the positive effects of specific enterprise-level policies may not be automatically forthcoming.

First, we find no support for the hypothesis that productive efficiency is a positive function of the firm's export orientation, ceteris paribus. Our microeconometric evidence thus suggests that the positive correlation found between exports and GNP growth in several comparative studies is not generated by a positive effect of enterprise export orientation on productive efficiency. Our finding is, of course, consistent with the hypothesis that enterprise export orientation is conducive to allocative efficiency - a link which at the macro level could manifest itself in a positive correlation between exports and GNP growth. Alternatively, since we estimate our equations by instrumental variables, it is possible that the difference in the micro and macro findings comes about because we avoid the endogeneity bias that Jung and Marshall (1985) claim is present in the aggregate studies. In either case, our findings suggest that the export bent of the structural adjustrnent pulicies which have been pursued in Yugoslavia since 1982 ought to be justified on other grounds than productive efficiency.

The lack of support for the hypothesis that joint ventures benefit from superior managerial and technical know-how and hence achieve greater productive efficiency may be attributable to the fact that many Yugoslav firms rely heavily on western technology, thus possibly limiting the efficiency impact of a joint venture partnership. Nevertheless, our finding should be treated as a warning that joint ventures may not bring about the tremendous gains that are nowadays expected of them in Central/East Europe and the USSR.

Otr results also indicate that productive efficiency of firms is independent of the number of workers per division (BOAL). Paradoxically, one of the principal features of the 1989 Law of Enterprise is the phasing out of the divisional system of firms. The results of this study suggest that basing this 
systemic change on the expectation of a ignificant gain in productivity would be inappropriate.

Product market concentration, which has frequently been argued to cause serious distortions, displays positive (simple) correlation with average labor productivity. However, it is found to have no significant effect on productivity in the multivariate framework.

Finally, we find that productive efinciency is on average $18-20$ percent higher in the more developed republics and autonomous provinces (RAPs) than in the less developed ones. This estimate is statistically significant when the RAPs are divided into these two blocs, but the result is less significant when we try to identify RAP-specific efficiency levels by means of individual RAP dummy variables. These findings indicate that inter-regional differences in productive efficiency are significant but not as high as one might expect from the regional income per capita figures. The latter findings suggest that the problems of firms in developing regions may stem more from misallocation of resources than productive inefficiency. Further research in this important area is clearly needed before the source of regional differences can be fully identified.

Overall, our results indicate that the issue of structural transformation of socialist enterprises is a complex one and that a more detailed investigation of the factors affecting enterprise productivity is needed.

\section{Appendix}

\section{Data and the variables}

The data were gathered by a research team led by Janez Prasnikar in 1980-1981. The firms were selected as a 5\% stratified (by region and industry) random sample of work organizations (WOALs). All values are in thousands of dinars expressed in 1975 prices. The variables used in our empirical work are de.ined as follows:

$Q=$ valued added $=$ total labor costs + total capital costs + surplus $=$ Revenue material costs;

$K=$ capital $=$ fixed capital at historical cost (purchase value of capital) adjusted for capacity utilization;

$L=$ labor $=$ number of unskilled worker equivalents given by

$$
L=\sum_{i=1}^{8}\left(\frac{I_{i}}{I_{1}} L_{i}\right)
$$

where, $L=$ number of unskilled equivalent wukers in the firm, 
$I_{i}=$ average income of skill $i$ in the Yugoslav industry, $L_{i}=$ number of workers in the $i$ th skill group in the firm;

Export/revenue = the value of firms's exports/firms's revenue;

Labor/BOAL $=$ number of workers/number of BOALs relative to the industry mean;

Joint venture dummy $=1$ for firm operating as a joint venture with a foreign partner and 0 otherwise; market share =firm's sales as a proportion of its relevant product market. In view of the significant regional fragmentation of the Yugoslav product market, the construction of market share variable was not an easy task. The research team examined the relevant market with each enterprise director and constructed the variable on the basis of enterprise and regional data.

\section{References}

Amemiya, T. and T. MaCurdy, 1995. Instrumental-variable estimation of an error-components model, Econometrica 54, no. 4., \& ;9-880.

Bajt, A., 1983, The economic growth in Yugoslavia, paper presented at the Ninth International Seminar on 'Economic growth revisited: East and West, Florence, 8-10, 26.

Balassa, B., 1978, Exports and economic growth: Further evidence, Journal of Development Economics 5, no. 2, 118-190.

Balassa, B., 1985, Exports, policy choices, anc econounic glowtis in developiing countries after the 1973 oil shock, Journal of Development Economics 18, ne. 1, 23-26.

Balassa, B., 1986, Adjustment policies in socialist and private market economies, Journal of Comparative Economies 10, no. 2, 138-159.

Bateman, D.A., M. Nishimizu and J. Page, 1988, Regional productivity differentials and development policy in Yugoslavia, 1975-1978, Journal of Comparative Economics 12, no. 1, $24-42$.

Bazier-Madzar, M., 1972, Dugorocni tehnicni i tehnolcski razvoj privrede sa interpretacijom ekonomskih efekata (JER, Beograd).

Engle, R.F., 1982, A general approach ti) Lagrange multiplier model diagnostics, Journal of Econometrics 20, 83-104.

Estrin, S., R.E. Moore and J. Svejnar, 1988, Market imperfections, labor-management and earnings differentials in a developing country: Theory and evidence from Yugoslavia, Quarterly Journal of Economics.

Estrin, S. and J. Svejnar, 1985, Fxplanation of earnings in Yugoslavia: The capital and labour schuj:; compares., Econoinic Anaiysis and Workeis Managerncint 19, no. 1, 1-12.

Estrin, S., 1984, Self-management: Econom:c analysis and Yugoslav practice (Cambridgf. University Press, Cambrid ge).

Fallenbuchl, Z., 1983, East-West technology transfer: Study of Poland 1971-1980 (OECD, Paris).

Frankovic, V., 1967, Produkcijske Funkcije I, II, III (Institutza ekonomska raziskovanja, Ljubljana).

Gallant and Jorgenson, 1978, Statistical inference for a system of simultaneous, non-linear. implicit equations in the context of instrumental variable estimation, Journal of Econometrics $11,275-302$.

Gomulka, S. and S. Ostojic, 1984, Innovation activity in the Yugoslav economy, Mimeo.

Hausman, J.A., 1978. Specification tests in econometrics, Econometrica 46, no. 6, 1251-1273.

Hausman, J.A. and W.E. Taylor, Panel data and unobservable individual effects, Econometrica 49 , no. 6, 1377--1398.

Horvat, B., 1969, Tehnicki progress u Jugosiaviji, Ekonomska Analiza, 29-57.

Horvat, B., 1971, Business cycles in Yugoslavia, Eastern European Economics 9, nos. 3-4. 
Hsiao, C., 1987, Analyses of panel data (Cambridge University Press, Cambridge).

Jones, D. and J. Svejnar. 1985, Participation, profit sharing, worker ownership and efficiency in Italian producer cooperatives, Economica 52, 449-465.

Jung, W.S. and P.J. Marsiali, 1985, Exports, growth and causality in developing countries, Journal of Development Economics 18, no. 1, 1-12.

Kemme, D., 1987, Productivity growth in Polish industry, Journal of Comparative Economics 11, no. $1-20$.

Kiviet, J.F., 1985, Model selection test procedures in a single linear equation of a dynamic simultaneous system and their defects in small samples, Journal of Econometrics 28, 327-362.

Kuh, E., 1963, Capital stock growth: A micro-econometric approach (North-Holland, Amsterdam).

Michaely, M. 1979, Exports and growth: A reply, Journal of Development Econonics 6, no. 1, 141-143.

Nakamura, A. and M. Nakamura, 1981, On the relationship among several specification error tests presented by Durbin, Wu and Hausman, Econometrica 49, 1583-1588.

Nishimizu, M. and J.M. Page, Jr., 1982, Total factor productivity growth, technologcal progress and technical efficiency change: Dimensions of productivity change in Yugoslavia, 1965-1978, Economic Journal 92, no. 368, 920̈-936.

Petrin, T., 1981, Analiza vzrokov koncentracije organizacijskih enot $v$ industriji in trgovini Jugoslavije v letih 1954-1978 (RCEF, Ljubljana).

Pjanic, Z., 1983, Proces Samoupravnog Udruzivanja i jedinstvo Yugoslovenskog trzista, treci program, 41.

Prasnikar, J., 1983, Teorija i praksa organizacije udruzenog rada (Cekade, Zagreb).

Prasnikar, J. and J. Svejnar, 1988, Enterprise behavior in Yugoslavia, in: Advances in the economic analysis of participatory and labor-managed firms 3, 237-312.

Pucko, D., 1974, O nekaterih odprtih vprasanjih odnosa podjetje-temeljna organizacija zdruzenega dela, Ljubljana, Ekonomska revja, 199-209.

Sacks, S.R., 1983, Self-management and efficiency: Large corporations in Yugoslavia (George Allen and Unwin, London).

Sapir, A., 1980, Economic growth and factor substitution: What happened to the Yugoslav miracle?, Economic Journal 90, 294-313.

Sargan, J.D., 1958, The estimation of econometric relationships using instrumental variables, Econometrica 29, 393-415.

Spanos, A., 1986, Statistical foundations of econometric modeling (Cambridge University Press, Cambridge).

Terrell, K., 1990, Technical change in socialist industry: Evidence from Poland, Working paper no. 263 (Economics Department, University of Pittsburgh).

Tyson, L., 1980, The Yugoslav economy system and its performance in the 1970s, Research series no. 44 (Institute of International Studies, University of California, Berkeley).

Vanek, J., 1970, The general theory of labor-managed market economies (Cornell University Press, Ithaca, New York).

Vujkovic, T., 1972, Kvantitativina anuliza tecinnickog progresa, Zagreb.

Weitzman, M., 1970, Soviet postwar economic growth and capital-labour substitution, American Economic Review 60, 676-692.

Weitzman, M., 1979, Technology transfer to the USSR: An economic analysis, Journal of Comparative Economics 3, 167-177.

Whitesell, R., 1985, The influence of central planrings on the economic slowdown in the Soviet Union and Eastern Europe, Economica 52, 235-244.

World Bank, 1983, Yugoslavia, adjustment policies and development perspective (The World Bank, Washington, DC).

Wu, D., 1973, Alternative tests of independence between stochastic regressors and disturbances, Econometrica 41, 733--750. 